\title{
HIGHER SCHOOL TEACHERS’ DIGITAL COMPETENCE: STRATEGIES FOR SELF- ASSESSMENT AND IMPROVEMENT
}

\author{
Oleksandr Malykhin \\ Institute of Pedagogy of the National Academy of Educational Sciences of Ukraine, Ukraine \\ Nataliia Aristova \\ Institute of Pedagogy of the National Academy of Educational Sciences of Ukraine, Ukraine \\ Vasyl Kovalchuk \\ Oleksandr Dovzhenko Hlukhiv National Pedagogical University, Ukraine \\ Tetiana Opaliuk \\ Kamyanets-Podilsky Ivan Ohienko National University, Ukraine
}

\section{Taras Yarmolchuk}

Institute of Pedagogy of the National Academy of Educational Sciences of Ukraine, Ukraine

\begin{abstract}
The paper was aimed at examining higher school teachers' strategies for selfassessing and improving digital competence and finding out the range of the most effective and innovative ones. The research sample consisted of 115 higher school teachers from four higher educational establishments in Ukraine. The research sample was selected with the use of a non-random sampling technique. Personal data of research sample were taken into consideration i.e. demography, gender balance, age and specialty. The research strategy for collecting empirical data combined a web-based questionnaire, individual interviews, conversations with respondents and analysis of reflexive texts. The collected empirical data were then analyzed both quantitatively and qualitatively. The data were processed by means of Microsoft Excel 2016 and verified by Chronbach' Alfa (An Index of Reliability). During the development of a web-based questionnaire the authors defined seven cognitive contentcomponents of higher school teachers' digital competence and each of them was given a synthetic index. The obtained findings showed that higher school teachers had different levels of digital competence: ranging from low to high, and revealed the diversity in peculiarities of its manifestations and ways of thinking when operating the competence mentioned. The research results served as the basis for offering innovative strategies for self-assessing and improving higher school teachers' digital competence.

Keywords: cognitive content-component, digital competence, higher educational establishment, higher school teachers, strategies for self-assessing and improving digital competence.
\end{abstract}


Malykhin et al., 2020. Higher School Teachers'Digital Competence: Strategies for SelfAssessment and Improvement

\section{Introduction}

Technological advances that are an indispensible part of human life and affect every aspect of today's society continue changing requirements concerning personal and professional skills of experts in various fields. To positively contribute to world community and community you live in and to try to achieve considerable success, it is not enough to be just clever. In order to live a fulfilling life anyone should possess "a wide range of skills and competences and to develop them continually throughout life" (European Commission, 2018, p. 1). And although all competences are considered to be equally important, digital one offers infinite opportunities for improving formal, non-formal and informal learning, for shaping learning experience of different groups of learners and students, for providing educational information etc. Involving "the confident, critical and responsible use of, and engagement with, digital technologies for learning, at work, and for participation in society" (European Commission, 2018, p. 4), digital competence provides individuals with the possibility to achieve their full potential as effective agents of positive social change and highly qualified professionals and, what is more important, to participate fully in all aspects of life (Vuorikari, R., Punie, Y., Carretero Gomez, S., \& Van den Brande, G., 2016).

The advanced level of digital competence enhances experts' employability and improves their capacities through skills development and participation in professional learning networks by means of various information technologies and the Internet. And higher school teachers are not an exception. Providing formal, non-formal and informal learning, digital competence promotes higher school teachers' professional growth and development of their self-efficacy (Malykhin \& Aristova, 2018). In a today's world higher school teachers should be the agents of changes and play a key role in changing students' educational practices (Malykhin, 2016).

\section{Purpose and Tasks of Research}

The main objective of the paper is to examine higher school teachers' strategies for self-assessing and improving digital competence and to find out the range of the most effective and innovative ones.

The achievement of the main objective implies completing the following assignments:

1) to reveal the essence of existing higher school teachers' strategies for self-assessing and improving digital competence;

2) to define an innovative cognitive content-components structure of higher school teachers' digital competence and to give a synthetic index to all of them; 
3) to provide some practical guidance as for choosing methods and means for determining higher school teachers' digital competence level.

\section{Research Methodology}

\section{General Characteristics of Research}

The team of five researchers carried out the research from November to March, academic year 2018/2019. The research took place at four Ukrainian university, namely, Oleksandr Dovzhenko Hlukhiv National Pedagogical University (Hlukhiv, Ukraine), Kamyanets-Podilsky Ivan Ohienko National University (Kamyanets-Podilsk, Ukraine), National University of Life and Environmental Sciences of Ukraine (Kyiv, Ukraine) and Interregional Academy of Personnel Management (Kyiv, Ukraine).

\section{Research Sample}

The non-random sampling technique was used to select the research sample. The research sample included 115 higher school teachers. Personal data of research sample were taken into consideration i.e. demography, gender balance, age and specialty.

The demographic distribution of research sample is given in Table 1.

Table 1 Sample demographics

\begin{tabular}{|l|l|l|}
\hline Variable & $\begin{array}{l}\text { Number } \\
(\mathrm{N}=115)\end{array}$ & $\begin{array}{l}\text { Percentage } \\
(100 \%)\end{array}$ \\
\hline Gender & & \\
\hline Male & 55 & $47.83 \%$ \\
\hline Female & 60 & $52.17 \%$ \\
\hline Age & & \\
\hline$<=30$ & 18 & $15.65 \%$ \\
\hline $31-40$ & 39 & $33.91 \%$ \\
\hline $41-45$ & 28 & $24.35 \%$ \\
\hline$>=46$ & 25 & $21.74 \%$ \\
\hline No information about age & 5 & $4.35 \%$ \\
\hline Specialty & & \\
\hline Humanities & 43 & $37.39 \%$ \\
\hline Natural Sciences & 36 & $31.30 \%$ \\
\hline Maths and Technologies & 26 & $22.61 \%$ \\
\hline Information technologies & 10 & $8.70 \%$ \\
\hline
\end{tabular}

Source: own study

$N=115$ 
Malykhin et al., 2020. Higher School Teachers'Digital Competence: Strategies for SelfAssessment and Improvement

Figure 1 shows the distribution of respondents according to the gender criterion.

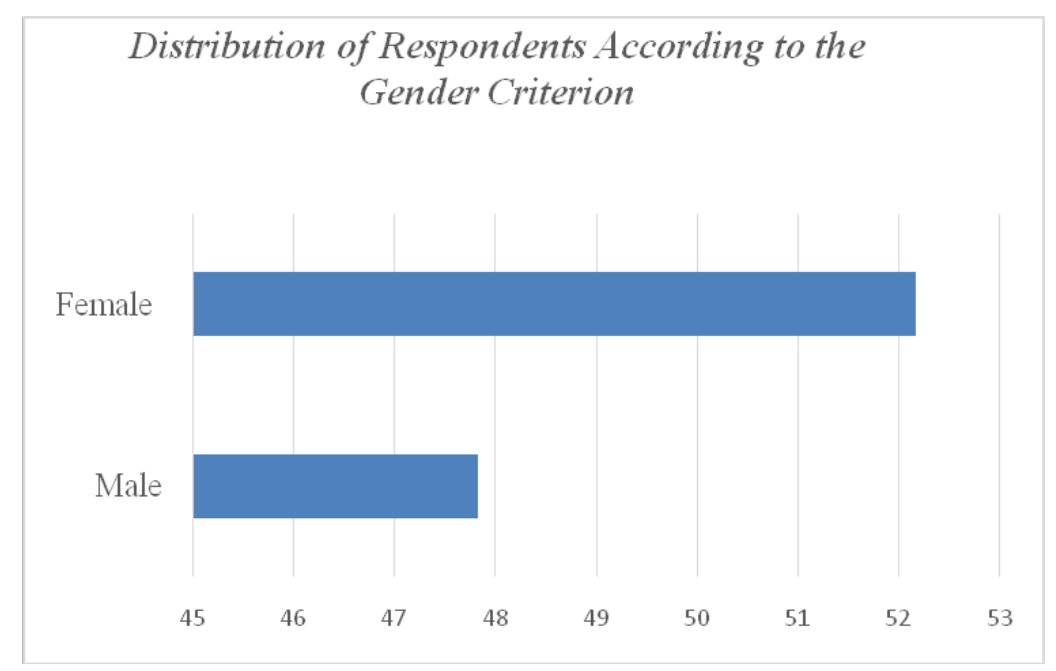

Figure 1 Distribution of respondents according to the gender criterion

The distribution of respondents according to the age criterion is demonstrated in Figure 2.

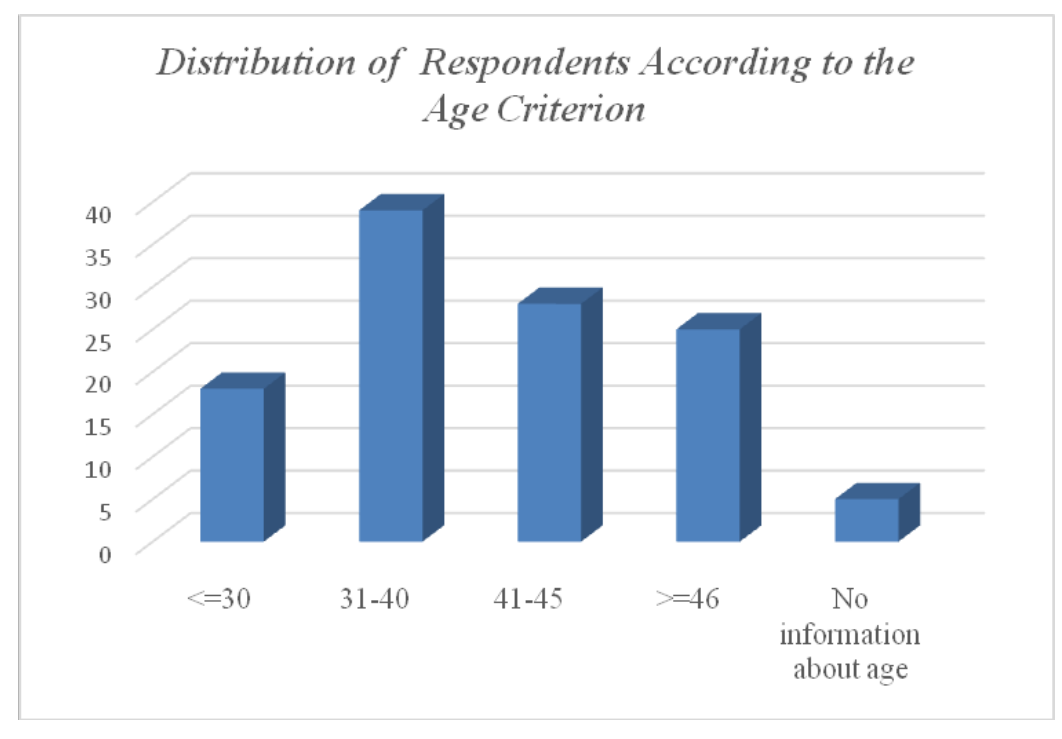

Figure 2 Distribution of respondents according to the age criterion

Figure 3 shows the distribution of respondents according to the specialty criterion. 


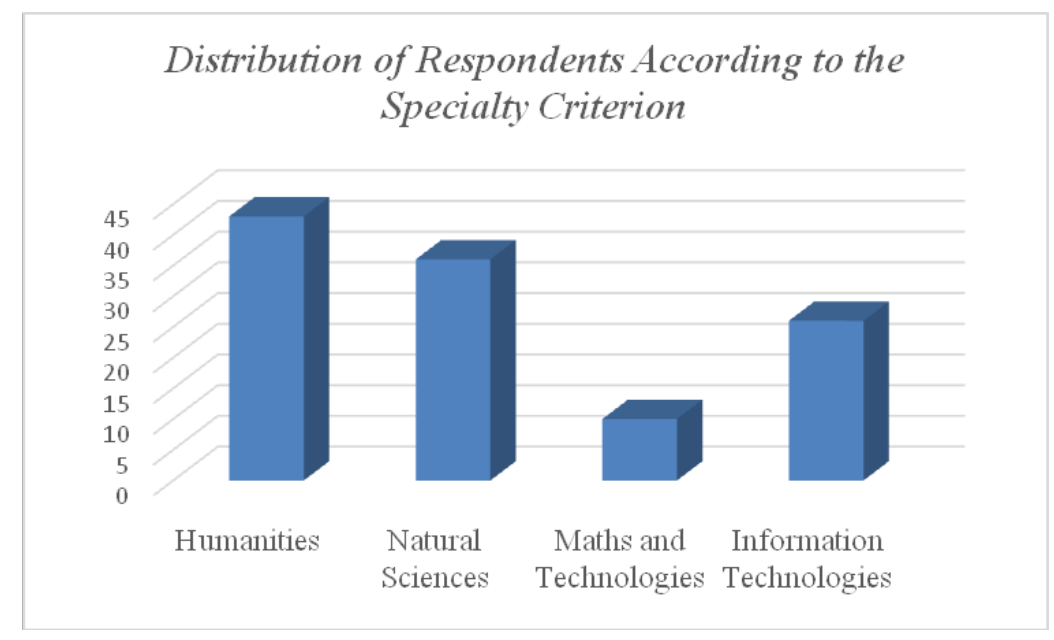

Figure 3 Distribution of respondents according to the specialty criterion

\section{Research instrument}

The research strategy for collecting empirical data combined a web-based questionnaire, individual interviews, conversations with respondents and analysis of reflexive texts. The web-based questionnaire developed by means of Survey Monkey (free online questionnaire tool) included 35 questions. The collected empirical data were then analyzed both quantitatively and qualitatively. The data were processed by means of Microsoft Excel 2016 and verified by Chronbach’ Alfa (An Index of Reliability). During the development of a web-based questionnaire the authors defined seven cognitive contentcomponents of higher school teachers' digital competence and each of them was given a synthetic index.

\section{Results and Discussion}

Table 2 demonstrates seven cognitive content-components of higher school teachers' digital competence.

Table 2 Synthetic index to cognitive content-components of higher school teachers' digital competence

\begin{tabular}{|l|c|c|c|c|}
\hline \multicolumn{1}{|c|}{ Cognitive content-components } & $\begin{array}{c}\text { Respondents } \\
(\mathrm{N})\end{array}$ & $\begin{array}{c}\text { Chronbach’ } \\
\text { Alfa }\end{array}$ & Sv & Sr \\
\hline $\begin{array}{l}\text { Combination of technological and } \\
\text { pedagogical knowledge, skills to know what }\end{array}$ & $\mathrm{N}=113$ & 0.890 & 0.911 & 3.917 \\
$\begin{array}{l}\text { opportunities are provided by different } \\
\text { information technologies in instruction } \\
\text { process }\end{array}$ & & & & \\
\hline
\end{tabular}


Malykhin et al., 2020. Higher School Teachers'Digital Competence: Strategies for SelfAssessment and Improvement

\begin{tabular}{|l|l|l|l|l|}
\hline $\begin{array}{l}\text { Knowledge and skills of using information } \\
\text { technologies for creating information content; } \\
\text { understanding of what information } \\
\text { technologies are the most suitable for } \\
\text { teaching definite disciplines }\end{array}$ & & 0.913 & 0.893 & 3.873 \\
\hline $\begin{array}{l}\text { Technological knowledge, knowledge about } \\
\text { information technologies and their } \\
\text { development }\end{array}$ & $\mathrm{N}=101$ & 0.825 & 0.810 & 3.212 \\
\hline $\begin{array}{l}\text { Pedagogical knowledge, knowledge about } \\
\text { teaching methods and teaching methods } \\
\text { implementation through using information } \\
\text { technologies }\end{array}$ & & & & \\
\hline $\begin{array}{l}\text { Content of knowledge which has to be } \\
\text { obtained for successful professional activity } \\
\text { in information society }\end{array}$ & $\mathrm{N}=104$ & 0.837 & 0.822 & 3.509 \\
\hline $\begin{array}{l}\text { Knowledge on pedagogy, learning and } \\
\text { teaching approaches corresponding to definite } \\
\text { disciplines and aims and purposes of } \\
\text { education }\end{array}$ & & & 0.836 & 3.720 \\
\hline $\begin{array}{l}\text { Technological and pedagogical content of } \\
\text { knowledge, intersection of technologies } \\
\text { concerning teaching methods and information } \\
\text { technologies }\end{array}$ & & 0.863 & 0.816 & 3.516 \\
\hline Note: N=number of respondents; Sv=standard deviation; Sr=average mean & & & \\
\hline
\end{tabular}

Source: own study

$N=115$

The analysis of higher school teachers' digital competence level corresponds with the levels described in "DigComp 2.1: The Digital Competence Framework for Citizens with eight proficiency levels and examples of use" (Carretero, Vuorikari, \& Punie, 2017) and is connected with the main research question how high school teachers assess their own digital competence. The following data contain the results of analysis of four levels of higher school teachers' digital competence, namely, foundation, intermediate, advanced and highly specialized. To make the presentation of material convincing, we quote some passages from explanations given by respondents with different levels of digital competence.

Foundation level of digital competence. Some higher school teachers think that their level of digital competence can be regarded as foundation, as they rarely use information technologies. Understanding that, although, students and other higher school teachers use different information technologies they believe that they also have to use them. Unfortunately, higher school teachers whose digital competence level is foundation are only able to search online for 
some information, do some simple tasks and use some information technologies to make instruction process more interesting:

"I have to admit that I am not an accomplished computer user. Everything I can do is to prepare presentations using Power Point. But to prepare them I have to ask for my students' or my colleagues' help. Although they are always ready to help and never refuse to help me, I am not comfortable with such a situation as nowadays information technologies are very important and highly required in the educational field". (Liudmyla)

The reasons for not using information technologies or for some limitations in using information technologies can be explained by the fact that for some respondents who represent ,the older generation of high school teachers" Information technologies do not play an important role in their work taking into account the lack of technical infrastructure, the financial gap and differences in technical opportunities between city education institutions and village ones that were in the past:

"When I started working 25 years ago we did not have many opportunities to use information technologies at work. We did not have enough computers at the workplace let alone the Internet or other information technologies. To tell the truth, there were computers and the Internet but they were not used for educational purposes. In most cases they were used by administration for managing the educational process. And buying a personal computer was a big deal. I understand that nowadays information technologies are becoming more and more important in all spheres of our lives but I find it very hard to improve the level of my digital competence". (Valeriy)

To sum up, we should note that for higher school teachers whose digital competence level is foundation and who prefer to use traditional teaching methods and techniques in instruction process the question on information technologies was not a simple one. However, despite that, they are ready to develop their digital competence either by doing some special courses at work or by attending some classes at special centres.

Intermediate level of digital competence. Higher school teachers whose digital competence level is intermediate one are able to understand, investigate and solve some problems connected with some use of information technologies according to their needs. The digital development process which is taking place in the present-day world society is one of the main factors that motivates higher school teachers to keep pace with the times and to use all the possible information technologies in instruction process. It is obvious that to be successful in the digital age anyone has to be digitally competent:

"To live successfully in the present-day society you have to adapt to various digital technologies. I believe that their use open up new opportunities for self-fulfilment in anyone's professional and personal lives. The higher level 
Malykhin et al., 2020. Higher School Teachers'Digital Competence: Strategies for SelfAssessment and Improvement

of your digital competence the higher level of competitiveness is ..." (Olha)

Many higher school teachers engaged in scientific activities understand that information technologies are becoming more and more relevant and necessary for future:

"As a teacher you have to know what your students' interests are. In most cases they are keen on computer applications and new digital gadgets". (Tetiana)

Thus, the use of information technologies is regarded as something new and beneficial:

"If you know how to use digital technologies and use them in instruction process you can get a dual benefit. At first, digital technologies provide a unique opportunity to ease teachers' work: you can search for the necessary information on the Internet and spread it among your students, use forums to communicate with colleagues and students, work with students and give feedback etc. And at second, digital technologies make the lessons interesting and unimitable”. (Iryna)

Other information technologies that were mentioned by respondents included email, game-based learning platforms, digital libraries, online learning platforms, smart-phones, notebooks etc.

We have to add that higher school teachers whose digital competence level was intermediate often do not understand how to use information technologies for teaching and learning. According to responses given by respondents it can be argued that the lack of understanding is connected, on the one hand, with the necessity to use innovative teaching methods that are also unclear for them, and, on the other hand, is the main reason for respondents' lack of self-confidence. These respondents explain that without experts' help it is very difficult to learn how to use information technologies:

"Before you start using a definite digital technology in instruction process you have to know exactly what to do, otherwise you will look and feel awkward". (Svetlana)

Respondents also add that they need more help and knowledge in order to use some information technologies in their everyday activity. Some of them even mention doing some courses aimed at improving their digital competence:

"I understand that digital technologies open up new opportunities both for students and teachers. But to keep up with technological advances and to be interesting to students you have to be digitally competent. As I am not as proficient as most of my students I am thinking about doing a course that will enable me to use digital technologies effectively to improve student learning". (Yuliia)

Advanced level of digital competence. At an advanced level where cognitive sphere is used and assessed the higher school teachers are able to solve 
different tasks and problems, direct others and adapt to students and colleagues in a complex context. Respondents with an advanced level of digital competence explain that information technologies can be used in order to make instruction process more varied:

"While learning disciplines I teach, students discover new things all the time as I try to provide them with the most updated information. I think teachers have to track the current progress in their area of expertise and digital technologies help them keep in step with scientific advances". (Oleksandr)

Besides, the obtained results show that information technologies are perceived as the support to teaching and learning process but not as its main focus. Higher school teachers with an advanced level of digital competence think that information technologies should serve as a means which motivates students to learn and get in-depth knowledge as well as a go-between students, teachers and knowledge:

"Being digitally competent teachers have to be able to understand what digital technologies can be used for teaching and learning". (Halyna)

To be competent in digital sphere is regarded as something necessary and compulsory in higher school teachers' work. One of respondents mentions:

"I consider a digital competence as one of the fundamental competences that has to be demonstrated by highly qualified experts specializing in various fields. Nowadays to be digitally competent is as important as to be literate. If you know how to read and write but you do not know how to use a computer and different applications you won't be able to do any job properly. I can even say that you won't be able to survive in a fast growing digital society". (Iryna)

Highly specialised level of digital competence. While evaluating and creating a cognitive domain, higher school teachers solve complex problems and tasks, make a significant contribution to professional practice and demonstrate a developed awareness of using information technologies in the educational process. The ability to evaluate and apply relevant information technologies in a variety of pedagogical settings is considered as a necessity and opportunity to vary the educational process with the use of multimodality to improve the education process.

Higher school teachers with such a level of digital competence transfer their knowledge by critiquing existing teaching and learning practices and developing new ones. The responses of respondents with a highly specialized level of digital competence are as follows:

"Existing information technologies are well integrated with learning goals but this process requires much effort and time in order to create and develop an individualized learning strategy". (Maryna) 
Malykhin et al., 2020. Higher School Teachers'Digital Competence: Strategies for SelfAssessment and Improvement

They know and understand the risks of using information technologies with educational aims. In addition, they see themselves as consultants (supervisors) who are able to help students use various information technologies in their learning process:

"Information technologies help teachers engage students in more effective ways of learning”. (Olena)

Having such a level of digital competence higher school teachers are able and ready to experiment with various information technologies and are constantly improving instruction processes. Moreover, they feel comfortable with both information technologies and the stated teaching and learning methods. The obtained results make it possible to claim that all higher school teachers who have a highly specialized level of digital competence share this point of view.

The survey shows a diverse range of results (Fig. 4). As we can see higher school teachers do not form a homogeneous group. Their education and experience in using information technologies are very different. Thus, 8 respondents $(6.96 \%)$ think that the level of their digital competence is highly specialized, 21 respondents (18.26\%) are convinced that the level of digital competence they possess is advanced. In its turn, 39 respondents (33.91\%) assess their digital competence level as intermediate and 47 respondents (40.87\%) - as fundamental.

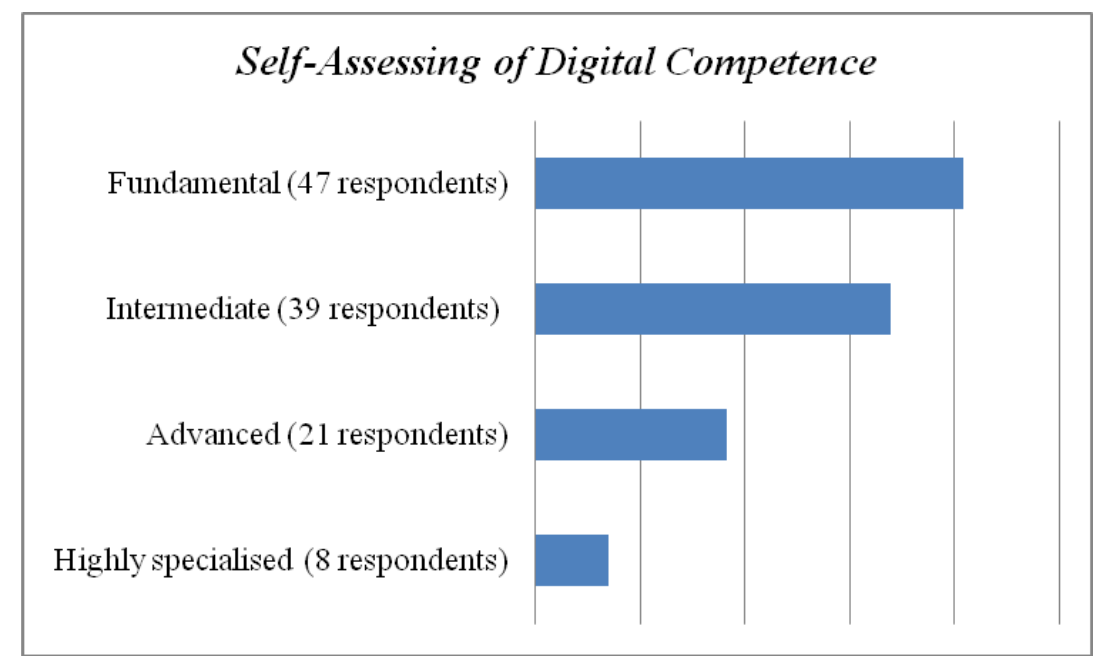

Figure 4 Self-assessing of digital competence by higher school teachers Source: own study $N=115$

The obtained findings demonstrate that although currently it is hard to imagine instruction process without using information technologies and all possible digital gadgets, the majority of higher school teachers participating in the research understand that their digital competence should be improved. Even 
some respondents who assess their digital competence level as highly specialized deeply believe they should increase their expertise participating in different workshops and doing special courses. But, unfortunately, not all respondents share the same point of view and have a positive attitude towards improving their digital competence. The promotion of motivation and improvement of access to additional education aimed at boosting higher school teachers' digital competence make a meaningful difference in instruction process.

\section{Conclusion}

The paper was aimed at examining higher school teachers' strategies for self-assessing and improving digital competence. For achieving the main objective the team of researchers has revealed the essence of existing higher school teachers' strategies for self-assessing and improving digital competence; has defined an innovative cognitive content-components structure of higher school teachers' digital competence and to give a synthetic index to all of them and has provided some practical guidance as for choosing methods and means for determining higher school teachers' digital competence level. As a result seven cognitive content-components of higher school teachers' digital competence have been defined and each of them was given a synthetic index. The obtained findings have shown that higher school teachers have different levels of digital competence: ranging from fundamental to highly specialised, and have revealed the diversity in peculiarities of its manifestations and ways of thinking when operating the competence mentioned.

\section{References}

Carretero, S., Vuorikari, R., \& Punie, Y. (2017). DigComp 2.1: The Digital Competence Framework for Citizens with eight proficiency levels and examples of use. [Data file]. Retrieved from https://publications.jrc.ec.europa.eu/repository/bitstream/JRC106281/ web-digcomp2.1pdf_(online).pdf

European Commission. (2018). Annex to the proposal for a council recommendation on key competences for lifelong learning. [Data file]. Retrieved from https://ec.europa.eu/ transparency/regdoc/rep/1/2018/EN/COM-2018-24-F1-EN-ANNEX-1-PART-1.PDF

Malykhin, O. (2016). Kompetentnisno-oriientovana paradyhma pidhotovky maibutnoho filoloha: monohrafiia / za red. prof. O. V. Malykhin. Kyiv: TOV “N VO Interservis".

Malykhin, O., \& Aristova, N. (2018). Investigation into participation activity rate of foreign languages teachers in specially focused network pedagogical communities. The New Pedagogical Review, 53(3), 227-238. DOI: 10.15804/tner.2018.53.3.19

Vuorikari, R., Punie, Y., Carretero Gomez, S., \& Van den Brande, G. (2016). DigComp 2.0: The Digital Competence Framework for Citizens. DOI: 10.2791/11517 